\title{
Proximal avulsion rupture of the flexor digitorum longus tendon associated with a medial malleolus ankle fracture
}

\author{
Naoki Yoshida, Yoshihiko Tsuchida
}

Department of Orthopedic Trauma Surgery, Shonan Kamakura General Hospital, Kanagawa, Japan

Correspondence to Dr Naoki Yoshida, n_yoshida@shonankamakura. or.jp

Accepted 2 September 2017
CrossMark

\section{To cite: Yoshida $\mathrm{N}$} Tsuchida Y. BMJ Case Rep Published Online First: [please include Day Month Year]. doi:10.1136/bcr-2017222231

\section{DESCRIPTION}

A 37-year-old man presented to the emergency department with right lower limb pain after being hit by an excavator. His right ankle was swollen, but no open wounds were observed. Radiography and CT of the right ankle revealed a medial malleolus ankle fracture (figure 1A,B).

During his treatment with osteosynthesis, a proximal avulsion rupture of the flexor digitorum longus (FDL) tendon from the musculotendinous attachment was discovered (figure 2). The flexor hallucis longus (FHL) tendon and posterior tibial neurovascular bundle were intact. The ruptured FDL tendon was interlaced through the FHL tendon and immobilised in a below-knee cast for 6 weeks. He showed a good functional outcome and had returned to work at the 5-month follow-up.

Proximal avulsion rupture of the FDL tendon associated with an ankle fracture is extremely rare. ${ }^{1}$ The mechanism of this injury is postulated to be that the valgus/adduction and external rotation forces at the ankle would cause maximal tensile force within the FDL tendon, causing it to avulse at the musculotendinous junction. ${ }^{2}$ When this occurs, ligamentous repair is recommended. ${ }^{3}$ In the context of an ankle fracture caused by atypical direct force, it is imperative to consider the possibility of avulsion rupture of the FDL tendon.

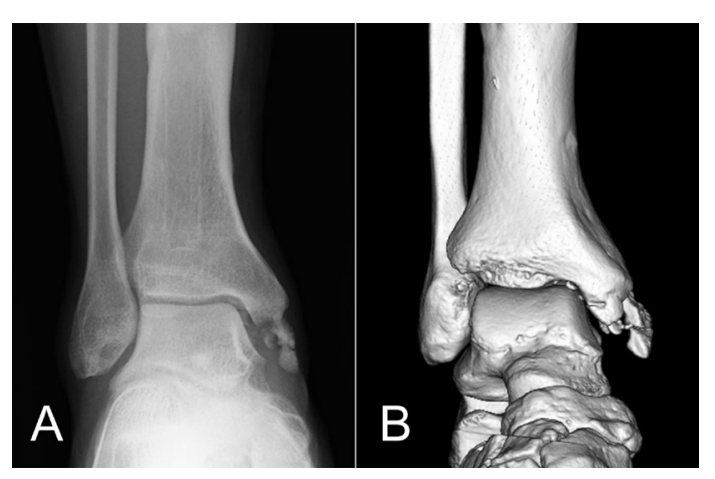

Figure 1 (A) Radiograph revealing a medial malleolus ankle fracture. (B) CT scan revealing a medial malleolus ankle fracture.

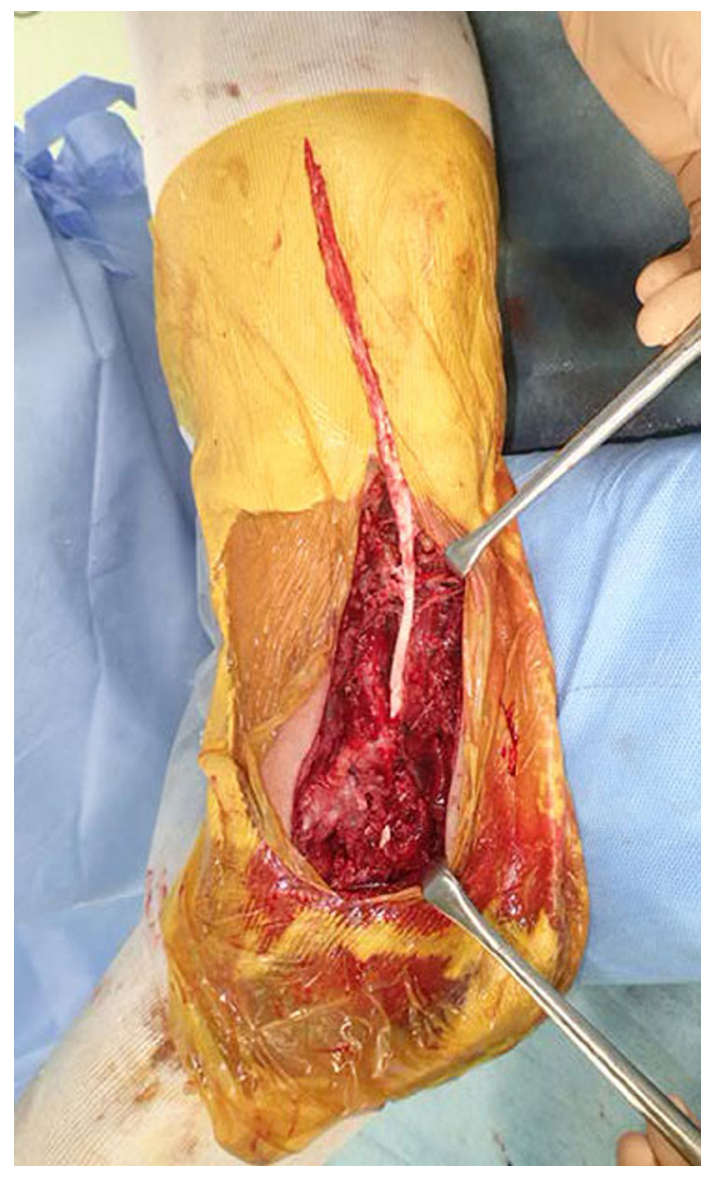

Figure 2 During osteosynthesis, a proximal avulsion rupture of the flexor digitorum longus tendon from the musculotendinous attachment was discovered.

Learning points

- Proximal avulsion rupture of the flexor digitorum longus (FDL) tendon associated with an ankle fracture is extremely rare.

- It is important to consider a possible proximal avulsion rupture of the FDL tendon while examining and treating an atypical ankle fracture.

Contributors The patient's care was overseen by NY and YT. YT provided assistance with the drafting of the manuscript. Both authors approved the manuscript prior to submission.

Competing interests None declared.

Patient consent Obtained.

Provenance and peer review Not commissioned; externally peer reviewed. 
(c) BMJ Publishing Group Ltd (unless otherwise stated in the text of the article) 2017. All rights reserved. No commercial use is permitted unless otherwise expressly granted.

\section{REFERENCES}

1 Heckman JD. Fractures of talus. In: Bucholz RW, Heckman JD, Rockwood and Green's Fractures in Adults. . 5th edn. Philadelphia: Lippincott Williams \& Wilkins, 2001:2. 109-12.

Copyright 2017 BMJ Publishing Group. All rights reserved. For permission to reuse any of this content visit http://group.bmj.com/group/rights-licensing/permissions.

BMJ Case Report Fellows may re-use this article for personal use and teaching without any further permission.

Become a Fellow of BMJ Case Reports today and you can:

- Submit as many cases as you like

- Enjoy fast sympathetic peer review and rapid publication of accepted articles

- Access all the published articles

- Re-use any of the published material for personal use and teaching without further permission

For information on Institutional Fellowships contact consortiasales@bmjgroup.com

Visit casereports.bmj.com for more articles like this and to become a Fellow
2 Ghani Y, Marenah K, Kumar PA. Isolated proximal rupture of flexor digitorum longus tendon in a traumatic open subtalar dislocation. Ann R Coll Surg Engl 2014;96:e10-2.

3 Elisé S, Maynou C, Mestdagh H, et al. [Simple tibiotalar luxation. Apropos of 16 cases]. Acta Orthop Belg 1998;64:25-34. 